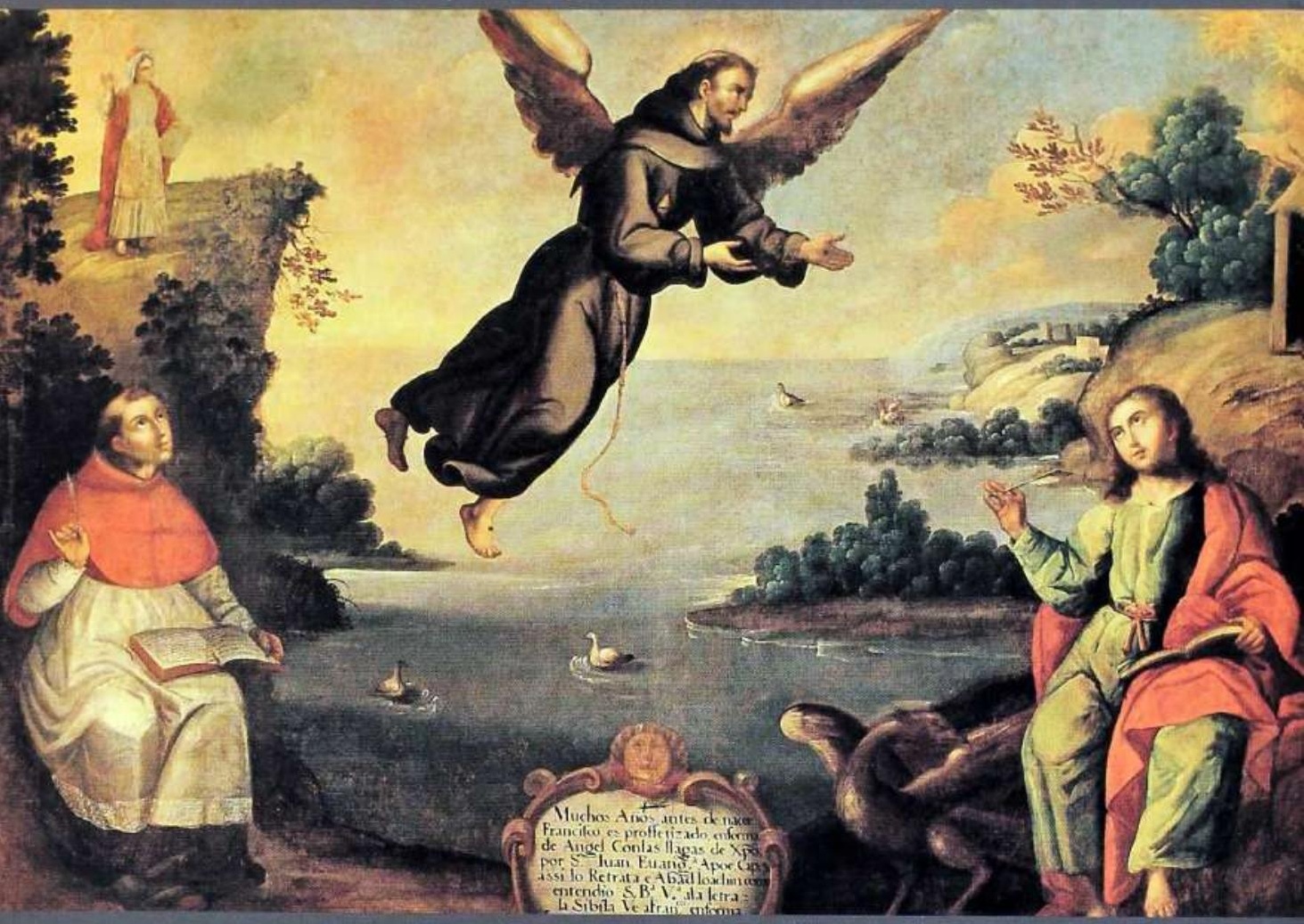

"La Profecia" atribuido a Basilio Santa Cruz y Juan Zapata Inca segunda mitad del siglo XVII. 


\title{
La invención de una arcadia andina: una aproximación a las figuras alegóricas de la pintura cusqueña La Profecía ${ }^{1}$
}

Constanza Acuña Fariña Universidad de Chile

\begin{abstract}
"El primer tiempo fue el de la ciencia, el segundo el de la sabiduría, el tercero será el de la plena inteligencia; el primero fue el de la obediencia servil, el segundo el del servicio filial, el tercero será el de la libertad". ${ }^{2}$
\end{abstract}

Gioacchino da Fiore, Concordia Novi

A finales del siglo XVII en la ciudad del Cusco, coincidió la separación de los artistas indigenas del gremio que compartían con los españoles, y la aparición de un movimiento de subversión al gobierno colonial inspirado en el milenarismo cristiano y en las corrientes escatológicas andinas.

La principal hipótesis de este trabajo es que el cambio de estilo que experimenta la pintura cusqueña a partir de ese momento -conocido como "estilo mestizo"-, está determinado por estos dos hechos. Esa transformación, estaba en ciernes en el programa iconográfico de la pintura La Profecía del círculo de pintores de Juan Zapaca Inca: un relato visual que va a interpretar los modelos europeos a través de una representación donde el devenir cronológico se interrumpe, introduciendo un tiempo mítico donde el paraíso bíblico se transforma en una arcadia andina con sibilas, arcángeles y profetas que anuncian la renovación profunda del mundo presente.

\section{Milenarismo / iconografía colonial / estilo mestizo / pintura cusqueña}

In late seventeenth-century Cusco the Escuela Cusqueña experimented a relevant change of style. This paper will argue that this transformation process, so-called "mestizo style," is extremely related to two apparently unconnected events. The first one refers to the separation of Spanish and native artists from the guild structure; the second revolves around the emergence of a subversive movement opposed to the colonial government based on Christian millenarianism and eschatological Andean currents of thought.

Through the analysis of the iconographic program of the painting La profecia by Juan Zapaca Inca and his circle of painters, this paper will interwove the events related to the guild's fracture and the emergence of this anti-government movement with the iconographic program of the painting. Within this context, attention will be paid to a visual narrative that reinterprets European models, an understanding of representation that breaks chronological evolution, and the introduction of a mythical time where the biblical paradise transforms in an Andean Arcadia with sibyls, archangels and prophets announcing the profound renewal of the present world.

Millenarianism / colonial iconography / mestizo style / Cusco painting

1 Este trabajo es parte de una investigación en curso titulada: "Estudio iconológico de la serie de pinturas que representan la vida de San Francisco de Asís en el Museo Colonial de Santiago de Chile" Fondecyt Regular $\mathrm{N}^{\circ} 1131071$.

2 Gioacchino da Fiore, fragmento del quinto libro Concordia Novi ac Veteris Testamenti, en la introducción de Sull' Apocalisse, Milano, Feltrinelli, 1994, p, 48. Traducción propia. 
El punto de partida de este trabajo es la interpretación de algunas alegorías de La Profecia, cuadro cusqueño de la segunda mitad del siglo XVII, que es parte del ciclo de 54 pinturas que representa la vida de San Francisco de Asís; serie que se encuentra en el Museo Colonial de Santiago ${ }^{3}$, y cuya autoría es atribuida al círculo de pintores de Basilio Santa Cruz y Juan Zapaca Inca.

Para este grupo de pintores indígenas cusqueños, fue decisiva la división oficial en 1688 de los artistas españoles, con quienes compartían oficialmente el gremio de acuerdo a las Ordenanzas de Lima de 1649.

Por la misma época en que estos pintores se independizaban de los artistas españoles, apareció en torno a la ciudad del Cusco un mito mesiánico que hablaba de la resurrección de Inkarrí, el dios vencido por el dios cristiano. El mito explicaba el origen de la sociedad colonial y su destino final, el que avendría cuando Inkarrí regresara y el mundo volviera al tiempo sagrado, el que existía antes de que los conquistadores invirtieran la cosmovisión andina.

Los primeros en difundir las creencias milenaristas cristianas en América fueron los franciscanos, específicamente su fracción espiritualista, que habían hecho suyo el pensamiento escatológico del abad Joaquín da Fiore, personaje que con sus reveladoras teorías acerca de la Trinidad, despertó no pocos problemas a la tradición escolástica de la Iglesia Católica de finales del siglo XII. ${ }^{4}$

El pensamiento joaquinista conquistó a los franciscanos, gracias a su visión profética, que se iniciaba con una original interpretación del Apocalipsis de San Juan Evangelista y culminaba sosteniendo que el reino milenario de Cristo solo sería posible con una transformación radical de las condiciones existentes en la historia terrenal.

Joaquín da Fiore había elaborado una concepción teológica de la historia dividiendo simbólicamente al tiempo en tres edades: la del Padre, edad de la autoridad y que corresponde al Antiguo Testamento; la del Hijo, la edad de la fe, sucesiva a la venida de Cristo, y la del Espíritu Santo, la edad de la luz, del amor y de la libertad, que equivale al Tercer Estado, donde se cumplirán las promesas del Antiguo y Nuevo Testamento.

En el cuadro La Profecía aparecen junto a San Francisco las figuras de San Juan Evangelista, Joaquín de Fiore y la Sibila. También vemos a un pintor realizando esta misma pintura, y, arriba de su cabaña, la representación de tres soles con rostros humanos. Es indudable que al representar en una sola tela a estos personajes, el círculo de pintores cusqueños estableció una red de sentidos entre el pensamiento joaquinista y el movimiento milenarista andino Inkarri.

Esta pintura abría interrogantes acerca de las repercusiones que, para la cultura colonial, había tenido el pensamiento mesiánico cristiano. Pero también evidenciaba que el barroco americano no evocaba tardíamente la idea de un estilo europeo, sino que junto a la apropiación de la nueva fe, ponía en discusión el problema de la sobrevivencia de sus antiguas creencias. Sin duda las imágenes coloniales se abrían como un problema donde se ponían en discusión no solo los modelos artísticos, sino también el sentido religioso y social que identificaba a las nuevas imágenes.

3 Para la historia de la serie que se encuentra en Santiago, ver : Pereira Salas, Eugenio: Historia del Arte en el Reino de Chile, Santiago, Ediciones de la Universidad de Chile 1965, pp.62-63.

4 Especialmente importante para la divulgación de las teorías de joaquín de Fiore en América y también para el programa iconográfico de nuestra serie de pinturas, es el libro del franciscano español radicado en la ciudad de Cusco, Pedro de Alva y Astorga, Naturae Prodigium, gratiae portentum. Madrid 1650. Ver Constanza Acuña, cuña, "El franciscano Pedro de Alva y Astorga y el circulo del pintores de Juan Zapaca Inca: milenarismo y visualidad en la cultura cusqueña del siglo XVII. Revista (Argentina Universidad de San Martin Bs. As.) Eadem Ultraque Europa año 7 (Junio 2011), no 12. pp. 53-78. 


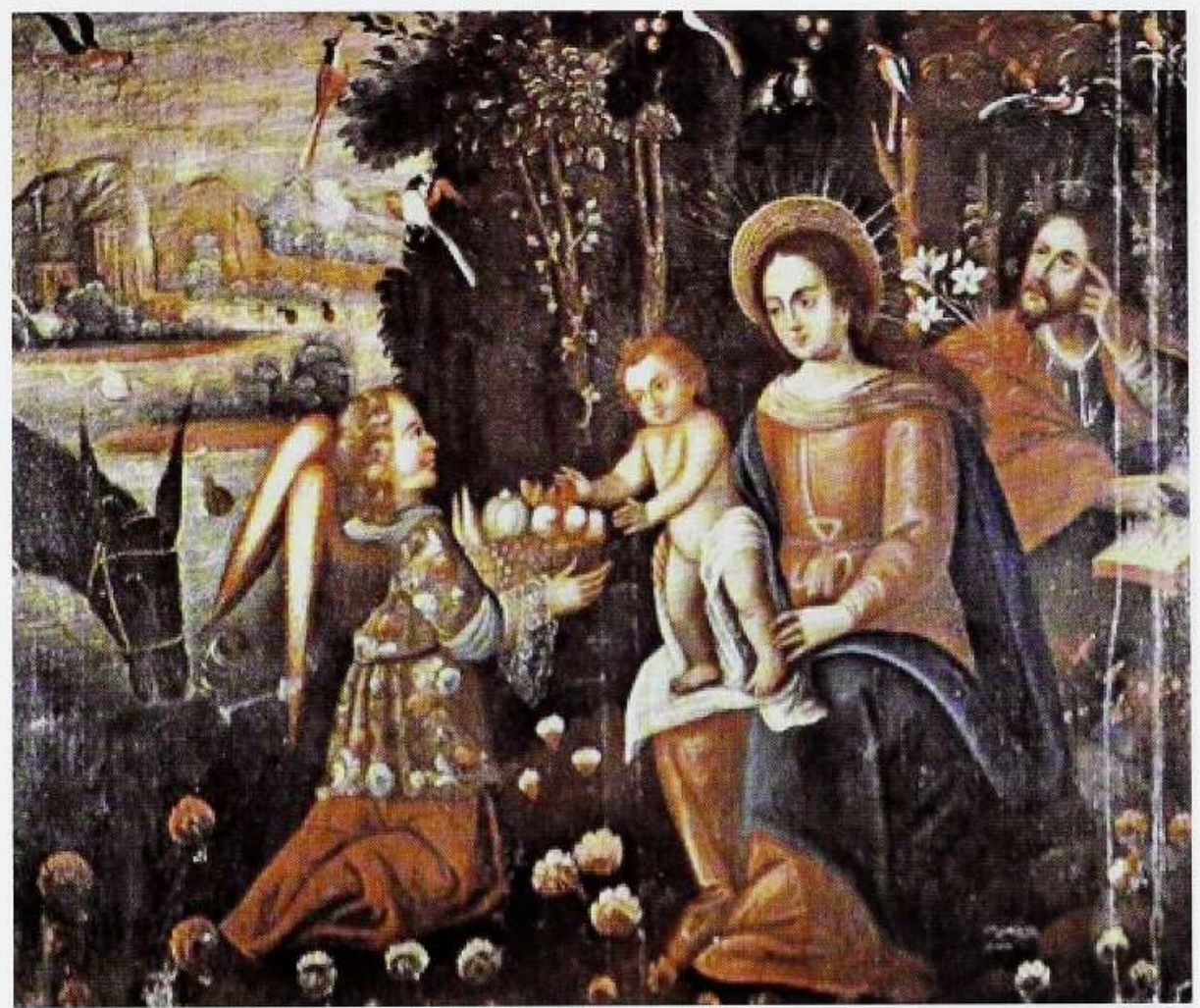

Anómimo cusqueño. Descanso en la Huida a Egipto, s.XVIII. Museo del Convento de la Merced, Santiago.

En referencia a lo anterior, mi artículo trata de entender la relación entre los movimientos de insurrección de los indigenas cusqueños y el nacimiento de un nuevo estilo pictórico que predominará durante todo el siglo XVIII, en el contexto colonial andino.

Se trata de una pintura donde aparece un paraíso terrenal, poblado por santos eremitas y ángeles apócrifos, rodeados de flores, frutos, y pájaros andinos.

Imágenes que invitan al espectador a un reino ideal, donde al igual que en la Arcadia clásica todas las contradicciones del drama de la existencia están resueltas en una perfecta armonía entre el hombre y la naturaleza. Es decir, una percepción del mundo opuesta a la concepción dinámica y racional -basada en las nuevas conquistas de la ciencia-que se impondrá en el arte europeo del siglo XVIII.

Por lo general, la historiografia colonial ha visto en ese cambio un retroceso respecto a la pintura más académica del siglo anterior.

Pienso, por el contrario, que ese giro arcaico no adopta las connotaciones peyorativas de las palabras en desuso, sino más bien señala la capacidad que tuvieron estos artistas de dar nuevas inflexiones a antiguos vocablos, de convertir en imágenes mnemónicas aquellos motivos que llegaban desde la actualidad europea. Es decir, contaminando la concepción lineal del tiempo, el presente adoptaba una dimensión donde la acción del pasado recobraba todo su sentido transformador. 


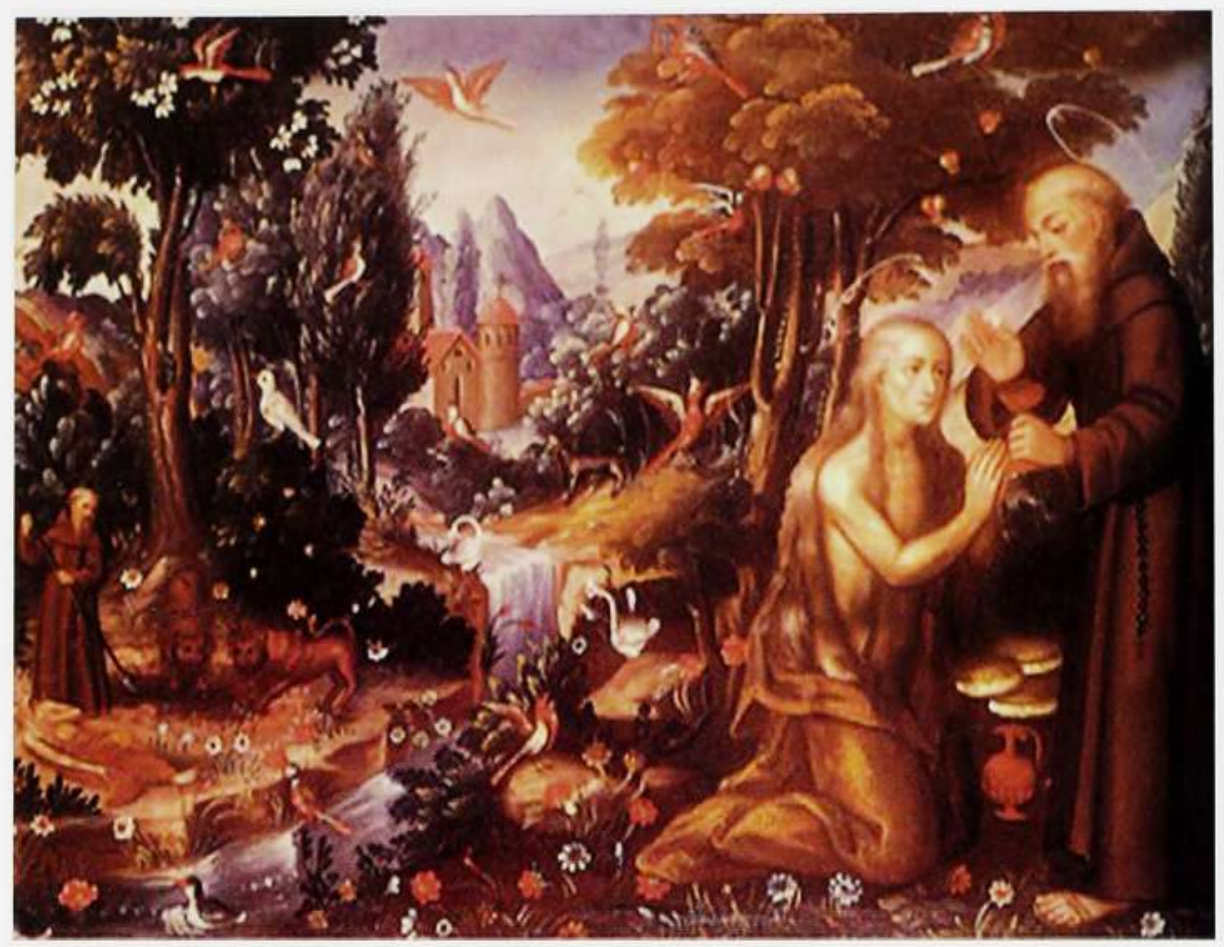

Escuela cusqueña, Santo Maria Egipciaca, s.XVII, Celso pastor de la Torre.

En La Profecía podemos identificar a los personajes del cuadro gracias a la cartela que se encuentra en el centro inferior, donde se puede leer:

Muchos años antes de nacer Francisco es Profetizado en forma de Ángel con las llagas de Cristo por San Juan Evangelista. Apocalipsis Cap.9. Así lo retrata el Avad Joaquin como entendio San Buenaventura a la letra. la Sibila ve a Francisco en forma de estrella.

San Francisco aparece en el centro del cuadro, volando hacia el extremo derecho, allí se encuentra San Juan Evangelista evocando un episodio del Apocalipsis. Al otro extremo, también con un libro abierto, está el "abad Joaquín".

San Juan Evangelista y el abad calabrés son representados respectivamente, sosteniendo el libro de sus profecías con la mano izquierda y la pluma en la derecha. A los pies del apóstol aparece el águila, su símbolo en la tradición cristiana. Justo arriba de abad Joaquín, en un acantilado y enmarcada por el follaje de algunos árboles, se encuentra la Sibila con dos soles sobre su cabeza. ${ }^{5}$

5 De acuerdo al estudio iconográfico realizado por Carmen García Atance de Claro, "Estudio iconográfico de la serie sobre la vida de San Francisco" en Barroco Hispanoamericano en Chile, vida de San Francisco de Asis, Madrid, Corporación 3c, 2003. pp 28-160; se trataría de la Sibila Eritrea (siglo Vl a.J.C.) la más antigua de todas las sibilas, a la que en el siglo XIII se consideraba la profetisa del Juicio Final; sin embargo, a partir del siglo XV pierde esta connotación para relacionarla con la escena de la Anunciación. Sus atributos iconográficos son tres: la flor de lis, propia de la Anunciación; una espada desnuda, por su vinculación al Juicio Final, y las tablas en las que aparecen escritos sus vaticinios. Por otro lado la autora ha identificado como fuentes textuales de la cartela los textos de fray Gerardo del Borgo, San Buenaventura y San Bernardino de Siena. 
En el extremo superior izquierdo se pueden observar tres soles: el primero aparece con una cara sonriente, el segundo serio, y el tercero semitapado por una espesa nube gris. Justo debajo de la triada solar se puede observar, dentro de una pequeña cabaña, a un pintor que realiza esta misma pintura.

Ese detalle -el retrato del pintor y el cuadro- es importante como antecedente para entender la voluntad de los artistas indígenas, que tras su separación del gremio que compartían con los artistas españoles, asumirán una independencia respecto a cómo llevar a cabo su trabajo, autonomía que se manifiesta en la necesidad de poner en cuestión el lugar que ocupaban como artistas en aquella red de convenciones sociales y culturales, y, sobre todo, en aprender a cambiar las reglas del arte, las doctrinas religiosas y los modelos que imponía el orden colonial para crear su sistema de representación oficial.

\section{La ruptura del gremio de los artistas cusqueños en 1688}

La petición del gremio de pintores españoles al Corregidor del Cusco durante 1688, se ha convertido para la historia del arte colonial en "la partida de nacimiento de la pintura mestiza cusqueña"6.

\section{El documento se refería a} la obligación-que tenían tanto los artistas indios como españoles- de levantar en conjunto los arcos para la fiesta del Corpus Cristi. Ese año se haría sin la participación de los indígenas, ya que estos últimos se negaban a trabajar junto a sus colegas europeos, alegando importantes diferencias de trato. Decían que "con violencia se les quita y se les agravia", y que muchos de los españoles actuaban como "capataces", que subcontrataban a los pintores indios

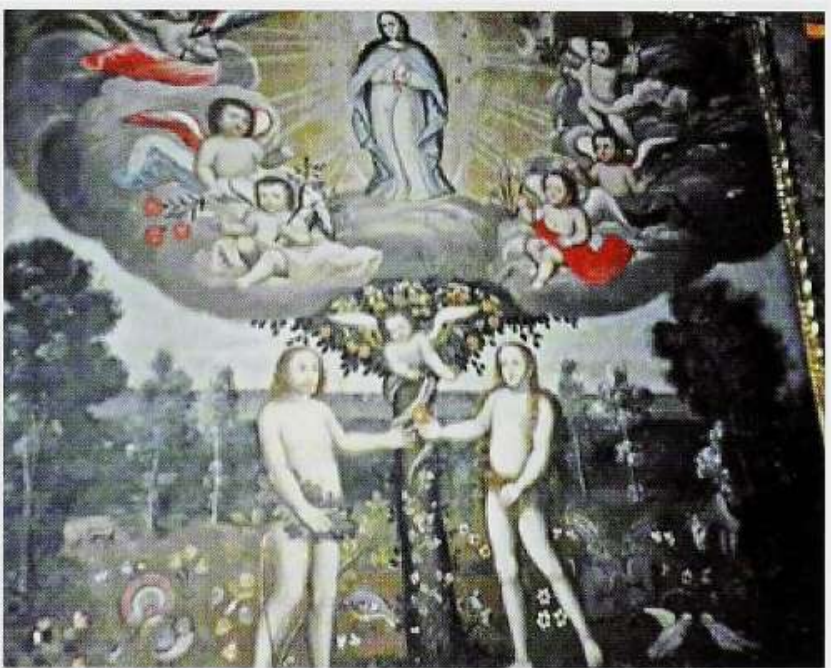

Círculo de Marcos Zapata. La Virgen, Adän y Eva, segunda mitad siglo XVIII, Iglesia de Huanoquite, Departamento de Cusco para realizar grandes encargos de cuadros para conventos e iglesias. Los españoles, a su vez, acusaban a los indígenas de "embriagarse y de levantar testimonios y juramentos falsos". La autoridad zanjó el problema fallando a favor de una separación, según la cual " los dichos indios hagan un año el arco triunfal y otro año los españoles". " Esta disputa reflejaba la típica tensión racial que durante los tres siglos del período colonial marcó la fisonomía de la nueva sociedad americana. Específicamente para la pintura cusqueña, esta división significó un cambio de ruta en la producción, el estilo y la difusión de sus pinturas. Mientras el gremio de los

6 Teresa Gisbert y José de Mesa, en su libro Historia de la Pintura Cuzqueria, Fundación Augusto N. Wiese, Lima, 1982.pg 137-138, analizan con profundidad los hechos y las consecuencias de la ruptura entre pintores españoles e indigenas, el documento de 1688 es presentado como "la partida de nacimiento del estilo cuzqueño".

7 Fondo Vega Centeno. Petición del gremio de pintores al Corregidor del Cuzco 1687-88 en Historia de la Pintura Cuzqueña, Fundación Augusto N. Wiese, Lima, 1982. Pgs. 137-138. 


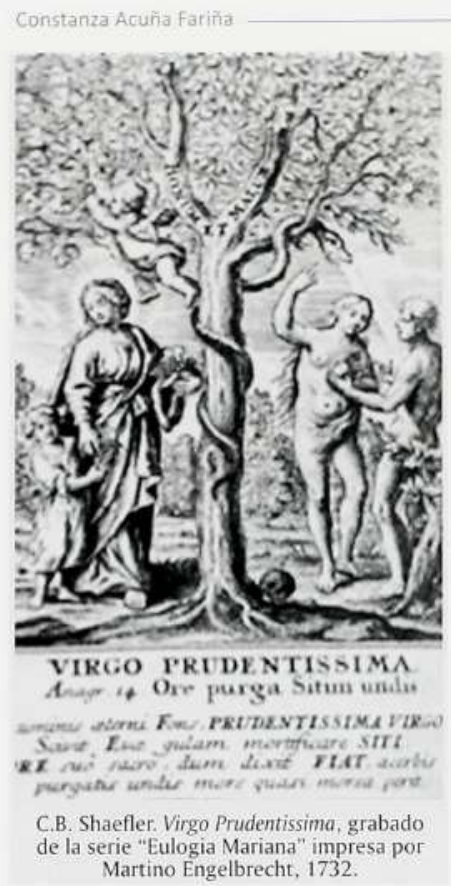

españoles siguió las ordenanzas redactadas en Lima en $1649^{8}$ que obligaba a todos los artistas a superar un examen para ejercer el oficio de escultor, dorador o pintor, los artistas indigenas disociados decidieron no volver a examinarse.

Nace entonces una pintura inspirada en la cultura popular, donde las historias se hacen menos retóricas y más anecdóticas, se multiplican las imágenes del Paraíso con Adán, Eva y la Serpiente, la Huida y el Retorno de Egipto, Eremitas y Santos como María Egipciaca. El paisaje comienza a ocupar un lugar predominante, el agua, el cielo y la tierra son descritos a través del efecto difuminado y predominante del rojo y el azul. Paisajes habitados por pájaros andinos que, encaramados entre el follaje de espesos árboles, o nadando por ríos y lagunas recuerdan la Edad del Oro.

Por otro lado, esta decisión de abandonar la institución gremial y académica que vigilaba el ejercicio artístico, tiene que ver con una acción política que atraviesa también otros ámbitos sociales que se debaten por una libertad y una independencia de acción respecto al sistema de poder colonial. En ese sentido, es importante ver las coincidencias simbólicas y temáticas con los mitos orales que recurren tanto a una interpretación del pensamiento milenarista cristiano, como a su reinterpretación andina por parte de movimientos de insurrección indigena; tal es el caso de Inkarrí, del que hacíamos una breve mención al inicio de este artículo.

\section{Los tres soles y la nube de La Profecía y su relación con el milenarismo andino}

El significado de los tres soles de La Profecia se encuentra, me parece, en la combinación de aquellos elementos - distintos a las figuras humanas- representados como: agua, sol, cielo, tierra, mar, nubes, vegetación, pájaros, y que podríamos resumir en la noción de naturaleza. Pero en realidad la pintura es, respecto a su significado, mucho más precisa y no se distrae en traducir un concepto tan vasto. La cifra de su intuición la vemos en un fenómeno natural que se puede imaginar observando detalladamente la pintura, y tal es la evaporación.

Nuevamente nos encontramos con la imagen de la nube gris que cubre al tercer sol, su ciclo de humedad y calor esta a punto de estallar en la fusión que da origen a todas las cosas.

Esa imagen de oposición fecunda que Ovidio nombró llama húmeda, los incas la resolvieron en la figura mítica de las Pacarinas, sitios sagrados (lagunas, manantiales, las aguas congeladas de las montañas) que tienen la cualidad de reproducir la vida a través de la concordia entre la mutua generación y destrucción de los elementos.

El agua que se transforma en vapor por efecto del sol y luego se condensa cayendo sobre la tierra en forma de lluvia, es un movimiento cíclico que sintetiza la acción creativa de las fuerzas naturales y de todo lo que experimenta una mudanza o una circulación infinita de una cosa en otra. Así, la figura de la nube y su ciclo de transformaciones, no es sólo un

8 Un importante estudio sobre el origen de las ordenanzas es el que ha realizado Gabriela Siracusano en su ensayo "Para copiar las "Buenas Pinturas" problemas gremiales en un estudio de caso de mediados del siglo XVII en Lima" en III Encuentro Internacional sobre Barroco, La Paz, 2005. Pp. 131-139. 
elemento "curioso" del telón de fondo de la historia del santo, sino una metáfora del sentido mítico de esta pintura y de toda su serie.

La imagen de la evaporación es parte de lo que podríamos llamar la naturaleza invisible del cuadro, la que aparece después que completamos - con nuestra interpretación-el instante vacio o el "entremedio" que siempre dejan las representaciones barrocas a la observación. Se trata, entonces, de un descubrimiento que se produce tras la reflexión móvil que va desde la percepción a la obra y de ella a una nueva comprensión.

Para finalizar mi argumento principal, que es ver en la pintura La Profecia los antecedentes de la invención del motivo de una arcadia andina, creo que el motivo de la nube gris que esta cubriendo parte de la cara del último sol y la cabaña del pintor, nos recuerda que esta pintura debe ser leida en clave alegóri$\mathrm{ca}$, es decir, como una imagen donde el sentido está en suspenso, o más bien a punto de ramificarse.

Los artistas mestizos privilegiaron la forma indirecta, el juego de alusiones y subentendidos:
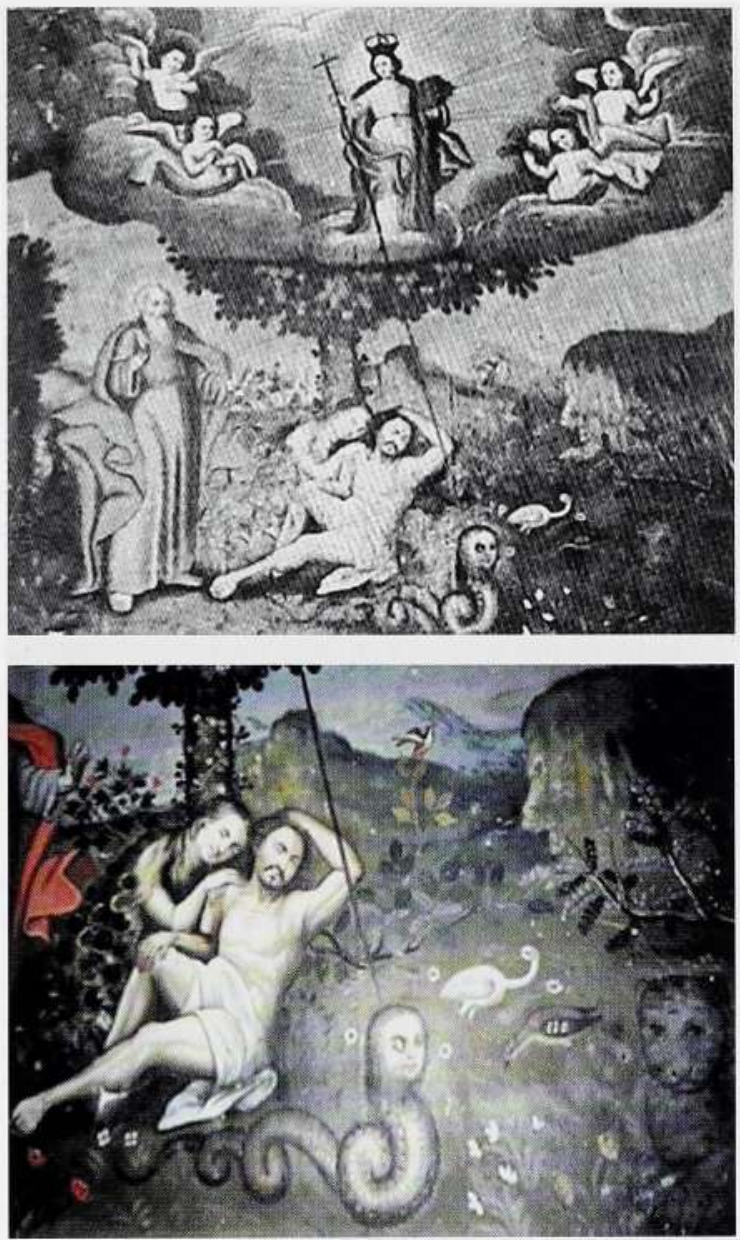

Círculo de Marcos Zapata. El Padre Eterno hace la promesa de la Inmaculada, segunda mitad del siglo XVIII, óleo sobre tela, Iglesia de Huanoquite, departamento de Cusco.

decir entre líneas o a medias, huyendo de los significados univocos. En este sentido, la efectividad del Artificio venía subrayada por una pregunta acerca del placer de ver aplicada una cosa para luego verla expresada en otra distinta: armar nuevas relaciones entre cosas sacadas de sus contextos originales las extraña de su sentido primero, obligándolas a vagar por significados ambiguos, momentáneos.

La alegoría marca su mayor distancia con el símbolo, precisamente en esa imposibilidad de establecer significados definitivos, en no fijar un sistema unitario entre los elementos que conviven en ella bajo una pugna en constante movimiento. Me parece ver que gran parte de la reticencia que despiertan tanto las alegorías como las pinturas coloniales, deriva precisamente de ese modo de ser indirecto.

El significado de los tres soles es sin duda el motivo más enigmático de esta pintura. A pesar de su evidente relación con las teorías mesiánicas de Joaquín de Fiore, no existen fuentes textuales que permitan documentar cómo fueron asimiladas y transformadas por 
los artistas cusqueños y difundidas entre los movimientos sociales andinos. Sin embargo, la transcripción de mitos orales andinos como el de Inkarrí y la concepción andina de las tres edades del mundo en un pueblo de las inmediaciones del Cusco -hecha por el antropólogo Enrique Urbano-, establecen evidencias que permiten introducir la imagen alegórica de los tres soles de La Profecía en una red de sentidos con el resto de la cultura andina.

Parte del relato transcrito por Urbano dice:

(...) una mañana salieron tres soles, tres soles en distintos lugares, pero de donde ahora sale, y los quemo a los ñaupas y machus, a toditos. Hoy solo se ven sus huesos y los restos de sus viviendas. Se metieron donde podían, unos a los manantiales, otros a los matorrales. Ahí estarán aun vivos, dicen. Este mundo terminará muy pronto y llegará la época del Espíritu Santo, y resucitarán los muertos y los que eran aun vivos y darán cuenta de sus pecados. Los buenos salen a la gloria y los malos al infierno .La gente de ese tiempo tendrá alas y vuelan donde quieren y solo comerán frutas. ${ }^{9}$

Al igual que Urbano el escritor José María Arguedas ${ }^{10}$ coincide en identificar la influencia del milenarismo cristiano en la cultura popular andina y específicamente en el desarrollo de movimientos de insurrección social -como Taki Ongoy e Inkarri-, porque el pensamiento escatológico era una condición de las propias tradiciones andinas.

El relato popular andino fue desarrollando una comprensión general del tiempo y el espacio más cercana a un género de palabra utópica, cuya característica principal es fijar, en un modelo ahistórico, una sucesión de tiempos divididos en partes contrastadas. Precisamente para aquello sirven las tres personas divinas de la Trinidad cristiana y las tres edades que proponía el abad Joaquín de Fiore.

El milenarismo, recogido por los movimientos andinos, funcionó como un modelo de resistencia frente a la aculturación. La imagen de la resurrección de un pasado mítico que incorporaba elementos de la cultura colonial, permitió establecer un espacio de sobrevivencia entre el pasado precolombino y el presente mestizo y colonial. Una mezcla entre el Paraíso cristiano, la arcadia clásica y el propio paraíso mítico que los pueblos andinos llamaron "huerto florido" o Hanacpacha."

\section{La figura Arcaica}

El uso de grabados se había difundido entre los pintores del Cusco desde el siglo XVI. Para los artistas americanos, los grabados se transformaron rápidamente en una técnica de aprendizaje accesible, económica y fácil de transportar. Se hablaba de los grabados como "el alfabeto de los artistas".12

9 Henrique Urbano, "Las tres edades del mundo. La idea de utopía y de historia en los Andes" en Mitos y simbolismo en los Andes. La figura y la palabra. Centro de estudios regionales andinos Bartolomé de las Casas, Cusco 1993.p.285.

10 José Maria Arguedas, Formación de una cultura nacional indoamericana. Siglo XXI editores, México D.F 1989. "Toda la literatura oral hasta ahora recopilada demuestra que el pueblo quechua no ha admitido la existencia del "cielo", de otro mundo que éste ubicado fuera de la tierra, y que sea distinto de ella, en el cual el hombre reciba compensaciones que repare las "injusticias" recibidas en este mundo... toda reparación, castigo o apremio se realiza en este mundo". p. 181.

11 Utilizamos el concepto de Hanacpacha a partir del estudio que hace de él Teresa Gisbert en El Paraiso de los pájaros pariantes.

12 Estudios fundamentales sobre el uso del grabado en el arte colonial peruano son los de Francisco Stastny, ver* La presencia de Rubens en la Pintura Colonial". Revista Peruana de Cultura, n4. Lima: 1965. http:/colonialart. org/essays/el-grabado-como-fuente-del-arte-colonial-estado-de-la-cuestion. Ver uno de los últimos estudios más relevantes sobre el tema en Thomas Werner, Stols Eddy, Un mundo sobre papel, libros y grabados flamencos en el Imperio Hispanoportugués (siglos XVI-XVIII) ACCO/Lovaina 2009. 
En Sudamérica, los grabados se transformaron no sólo en la manera más efectiva de ilustrar la función religiosa de las historias bíblicas y hagiográficas, también fueron la principal fuente de información iconográfica para los artistas locales.

Junto a la imagen de paraíso cristiano -a través de las imágenes reproducidas en libros de catequesis, de emblemas, de tratados de pintura, mitología y arquitectura- llegaron las imágenes y los relatos de la mitología clásica.

Después de un primer momento más doctrinario, la diversidad de imágenes que comienzan a formar parte del arte colonial durante el siglo XVII está relacionada, indudablemente, con una iconografía que se incorpora a través de las fiestas y procesiones religiosas, pero también imágenes clásicas que llegan a través de estampas en libros de mitología, tratados de emblemática, álbumes de artistas. Estas combinaciones de motivos heterogéneos, que no están limitadas por los contextos y los tiempos de los originales, es lo que produce al interior del arte virreinal peruano una relectura de los modelos europeos, desde una clave que llamaremos arcaica.

La palabra arcaico nos conduce a la palabra arca [lat. arca del tema arcêre "contener"], un mueble medieval similar a una caja destinado a conservar reliquias. También nos lleva al término archivo [archivum], entendido como el lugar y la técnica de conservación de documentos antiguos. La idea de articular el significado de un material primigenio, de registrar cosas que pertenecen a un tiempo perdido - del cual quedan solo restos- nos obliga a imaginar, a través de esos desechos, su estado anterior o mítico. Esta intención de recomponer la imagen de un pasado perdido, del cual no se puede establecer una continuidad, una forma cronológica, sino solo evocarla como una imagen poética, es una cuestión que atraviesa todas las poéticas del arte del siglo XVII, tanto en Europa como en América.

Sin embargo, es importante recordar que el Nuevo Mundo representó para Europa un lugar primitivo, de ficción, donde se imaginaba a sus habitantes en una Edad de Oro, un continente donde la riqueza y la exuberancia de la naturaleza se encontraban en perfecta sintonía con la inocencia de los nativos.

América representó, para muchos conquistadores, el lugar de la Utopía. El mundo andino, en modo particular el Perú, era la tierra fértil donde se escondía la mítica ciudad de El Dorado, un lugar donde abundaba el oro y las piedras preciosas.

Me parece que la invención de una Arcadia andina, recuperando el motivo de la arcadia clásica -como el lugar ideal para la creación poética, el amor, el reino donde están en justa armonía los sentidos y la reflexión-, representó para el arte colonial la posibilidad de superar la fractura entre el pasado precolombino y el presente colonial, especialmente a través de una invención alegórica.

La diferencia está en que para la mentalidad europea, la Arcadia asume el significado de un retorno a la Naturaleza, pero desde una clave contemplativa. Existe en ese sentido una consonancia entre las Bucólicas de Virgilio, la Arcadia de Sannazzaro, $y$ las pinturas de Ticiano, Guercino, o Poussin, como un sueño arqueológico y pastoral.

En la pintura cusqueña, en cambio, este antiguo motivo tomará un giro arcaico -en el sentido literario del término- como un juego de reciclaje de antiguos vocablos, a los cuales les viene designado un nuevo uso, una nueva dicción. Lo que sintetiza esta transformación es la incorporación de la mentalidad mesiánica, que ve el paraíso cristiano habitado por innumerables animales en una naturaleza exuberante; pero esta vez, en lugar de las evocaciones de un pastor melancólico, encontramos las voces graves y proféticas de las sibilas, de santos y eremitas que evocan el advenimiento de la justicia y de una renovación profunda del presente: el tiempo-ahora que anuncia Joaquín de Fiore en su Concordia. 